DOI: $10.14746 /$ por.2019.1.25

\title{
DLACZEGO DZIEDZICTWA MAJĄ ZNACZENIE: ODPOWIEDŹ NA ODCZYTANIA LEGACIES
}

\author{
Aviezer Tucker ${ }^{1}$ \\ (Harvard University)
}

\begin{abstract}
Słowa kluczowe: determinizm ekonomiczny, ścieżka zależności, populizm, postkomunizm, posttotalitaryzm, The Legacies of Totalitarianism Keywords: economic determinism, path-dependency, populism, post-communism, post-totalitarianism, The Legacies of Totalitarianism
\end{abstract}

\begin{abstract}
Abstrakt: Aviezer Tucker, DLACZEGO DZIEDZICTWA MAJĄ ZNACZENIE: ODPOWIEDŹ NA ODCZYTANIA LEGACIES. „PORÓWNANIA” 1 (24), 2019. T. XXIV, S. 285-292. ISSN 1733-165X. Jeżeli dziedzictwa totalitaryzmu mają znaczenie dla zrozumienia współczesności, pojawienie się populizmu w skali globalnej w posttotalitarnych, postautorytarnych i postliberalnych społeczeństwach po 2010 roku jest zastanawiające. Aby wyjaśnić to zjawisko trzeba odwołać się do pewnej wersji ekonomicznego determinizmu niż do historycznej ścieżki zależności. Argumentuję, że pewnym wspólnym mianownikiem populizmu jest zablokowanie społecznej mobilności. Elity bronią się przed utratą swojej pozycji poprzez zablokowanie ścieżek awansu klas niższych. Sposób zablokowania społecznej mobilności zależny jest od lokalnego kontekstu społecznego i politycznego. Rok 1989 przyniósł polityczną, lecz nie społeczną rewolucję. Elity społeczne późnego komunizmu przekształciły polityczny kapitał w gospodarczy, co uniemożliwiło wprowadzenie rządów prawa. W warunkach rozwoju gospodarczego efekty posttotalitaryzmu pozostawały w uśpieniu, recesja ożywiła je na nowo.
\end{abstract}

\begin{abstract}
Aviezer Tucker, WHY DOES HERITAGE MATTER: AN ANSWER TO READING LEGACIES. "PORÓWNANIA" 1 (24), 2019. Vol. XXIV, P. 285-292. ISSN 1733-165X. If the legacies of totalitarianism are significant for understanding the present, the global emergence of populism in post-totalitarian, post-authoritarian, and post-liberal societies since 2010 is puzzling. It seems to support some version of economic determinism rather than historical path dependency. I argue that the universal common denominator is blocked social mobility. The elites that protect them-
\end{abstract}

1 E-mail: avitucker@yahoo.com 
selves by blocking mobility and their social and political contexts are local. 1989 was a political, not a social revolution. The continuous late Communist elite transmuted political into economic capital and prevented the establishment of the rule of law. When economies and mobility expanded, the effects of the late totalitarian continuity laid dormant, the recession awoke them.

Pojawienie się współczesnego populizmu, demokratycznie wybranych rządów, które usiłują poszerzyć zakres władzy wykonawczej kosztem zmniejszenia lub zgoła wyeliminowania niezależności pozostałych władz, głównie sądowniczej i ustawodawczej, wykorzystując w tym celu niewielką przewagę, jaką uzyskały w ciałach przedstawicielskich lub poparcie niewielkich większości czy nawet dużych mniejszości wyborców do ograniczania praw mniejszości przy jednoczesnym manipulowaniu niespójnymi powszechnymi emocjami, a w szczególności strachem i niechęcią, do elit w celu wzmocnienia swojej władzy, jest zagadkowym zjawiskiem z punktu widzenia porównawczej perspektywy politycznej.

Ta swoista „cofka [liberalnej] transformacji”, jak nazwał ją Rafał Paweł Wierzchosławski, nie zaskakuje w przypadku państw i społeczeństw posttotalitarnych (Wierzchosławski). Dziedzictwem ery totalitarnej jest wszak słabość instytucji i liberalno-demokratycznych norm. Pomimo że społeczeństwa Europy Środkowej i Wschodniej były przez wieki wieloetniczne, wielokulturowe i wielowyznaniowe, w niecałą dekadę zostały ujednolicone - i odcięte od świata - przez dwa totalitaryzmy. Choć od upadku komunizmu społeczeństwa te dokonały znacznych, imponujących wręcz postępów ekonomicznych, ich gospodarki nadal pozostają w tyle w stosunku do pozostałych państw członkowskich Unii Europejskiej, co wywołuje frustrację. Choć to wyjaśnienie wydaje się wiarygodne, to nie tłumaczy ono jednak, dlaczego populizm ogarnął także takie zróżnicowane etnicznie i kulturowo państwa jak Stany Zjednoczone Ameryki czy Brazylię, kraje imigranckie i od dawna otwarte na świat. Stany Zjednoczone mogą się poszczycić trwającą od ćwierć tysiąclecia silną tradycją instytucji liberalno-demokratycznych. Brazylia ma wprawdzie tradycje autorytarne (lecz nie totalitarne), ale Stany Zjednoczone, powyżej linii Mason-Dixon - nie.

Ponadto zastanawiające jest porównanie rozmaitych populistycznych postkomunistycznych krajów: Polski i Węgier, z Czechami. Po 1989 roku na Węgrzech i w Polsce cyklicznie do władzy wracały partie postkomunistyczne. Jednakże teraz, o cokolwiek innego by nie oskarżać Wiktora Orbana i Jarosława Kaczyńskiego, ich polityczna przeszłość, podobnie jak polityczna przeszłość działaczy ich partii, jest czysta jak łza. Tymczasem w Czechach od 1989 roku izolowano politycznie komunistów, ale obecny populistyczny premier, euromiliarder, jest dzieckiem słowackiej nomenklatury i prawdopodobnie zdołał jeszcze za młodu, przed upadkiem reżimu, rozpocząć tajną współpracę z policji polityczną. Nie był, trzeba dodać, jakimś znaczącym współpracownikiem. Natomiast prezydent Zeman jest otwarcie prorosyjski, jego doradcy byli funkcjonariuszami komunistycznej tajnej policji, a jego kampa- 
nia prezydencka została opłacona przez Rosjan. Co więcej, wszyscy ci posttotalitarni populiści: premier Orban na Węgrzech, prezydent Miloś Zeman w Czechach, a nawet Jarosław Kaczyński w Polsce byli, w ciągu dwudziestu lat od 1989 roku, dość konwencjonalnymi politykami przestrzegającymi liberalno-demokratycznych reguł, a nawet podjęli kilka bolesnych niepopulistycznych decyzji gospodarczych. Aktualnych liderów Stanów Zjednoczonych czy Brazylii nie można nawet oskarżyć o to, że kiedykolwiek byli „normalni”.

Łatwo byłoby dojść do wniosku, że dziedzictwa i historia, czynniki długoi średnioterminowe miały niewielki wpływ na obecną historię polityczną. Po 1989 roku wyborcy z niższych klas średnich, biedniejsi, mniej wykształceni, starsi i z prowincji bez entuzjazmu tolerowali liberalną demokrację, ponieważ wierzyli, że ich wzbogaci, tak jak sąsiednich Niemców. Po fali recesji gospodarczej, która przyszła jak tsunami niczym z kosmosu, ich instrumentalna tolerancja liberalnej demokracji straciła swój raison d'etre. Populistyczni wyborcy powrócili do swych sprawdzonych późnototalitarnych politycznych zwyczajów. Ci politycy, którzy wyczuli zmianę klimatu, dostosowali sposób uprawiania polityki do wymogów demagogii, a plebs nie zważał na wiarygodność popieranych przez siebie demagogów, o ile tylko wyrażali oni jego odczucia i wystarczająco mocno krytykowali zastałe elity.

Grzegorz Lewicki zasadnie kwestionuje w swoich komentarzach wagę czynników średnioterminowych, które analizuję $\mathrm{w}$ The Legacies of Totalitarianism, w zestawieniu z czynnikami krótko- i długoterminowymi (Lewicki) natomiast Dragoş Petrescu podkreśla znaczenie teoretycznie podważanych wykształconych w długim historycznym trwaniu różnic pomiędzy społeczeństwami północnej a południowej części Europy Środkowo-Wschodniej (Petrescu). Być może globalna recesja z 2008 roku wpłynęła na kraje rozwijające się $\mathrm{w}$ taki sam sposób jak atmosfera jak fin-de siècle pod koniec lat dziewięćdziesiątych XIX wieku: złotego wieku wzrostu gospodarczego, postępu technologicznego i rozwoju handlu zagranicznego promującego kosmopolityczny, liberalny zeitgeist, wywołując zeitgeist globalnego populizmu niezależnie od dziedzictw totalitarnych, autorytarnych czy demokratycznych. Reszta jest historią w znaczeniu nadawanym temu powiedzeniu w Ameryce, a nie w Europie: nieważności raczej niż nieuchronności.

Taka analiza kusi swą prostotą. Jest jednak niepełna, ponieważ pomija średnioterminowe związki przyczynowo-skutkowe pomiędzy światowym kryzysem a lokalnymi populizmami. Szukane powiązanie musi więc być uniwersalne, a jednocześnie wywoływać te same rezultaty w bardzo różnych kontekstach społecznych. Według mnie najprawdopodobniejszą uniwersalną pośrednią zmienną jest zablokowanie mobilności społecznej. W obliczu kryzysu gospodarczy tort najpierw się wszędzie zmniejszył (oprócz Polski), a następnie przez dziesięciolecie w każdym kraju rósł zdecydowanie wolniej. Bez gospodarczego wzrostu awans społeczny jednych oznacza pogorszenie położenia społecznego innych. Zagrożone elity, które nie wiedziały, jak doprowadzić do ponownego wzrostu gospodarczego i pobudzić 
koniunkturę, zwarły szeregi i zablokowały awans jednostek w strukturze społecznej, aby zapobiec utracie swojej pozycji. Metody ograniczania mobilności społecznej, oficjalne i nieoficjalne, różnią się w zależności od społeczeństwa, podobnie jak struktury klasowe i sam charakter klas. Jednakże całkowite regulowanie mobilności społecznej zwykle wiąże się z przechwyceniem w pewnej mierze kontroli nad państwem, by zablokować ścieżki awansu społecznego i ochronić oligopole i przywileje. Politycy, którzy zostali dokooptowani przez elity, odbierani są jako skorumpowani i wkrótce $\mathrm{w}$ tym samym świetle postrzega się pozostałych nieskorumpowanych polityków. Słabe klasy społeczne zagrożone degradacją społeczną oraz poprzez kryzys i późniejszą stagnację pozbawione możliwości awansu, reagują strachem i złością na elity. Demagodzy manipulują tymi emocjami. Ponieważ elity w celu odróżnienia się od reszty społeczeństwa przestrzegają zasad grzeczności w Stanach Zjednoczonych ta uprzejmość elit kojarzona jest $\mathrm{z}$ „poprawnością polityczną" - populistyczni liderzy dowodzą swej odrębności od skompromitowanych elit przez wulgarne zachowanie i łamanie przyjętych w elicie zasad postępowania. Złość i urazy nie prowadzą jednak do rewolucji społecznej. Przewaga władzy jest tak duża, że obalenie elit wydaje się nie tylko niemożliwe, ale wręcz nie do wyobrażenia. Wyobraźnia uaktywnia się za to na myśl o grupach postrzeganych przez niższe klasy jako słabsze i podrzędniejsze - tak rodzą się ksenofobia, rasizm i szukanie kozła ofiarnego. Na tym kończą się międzynarodowe podobieństwa w aspekcie krótkoterminowych czynników, a pojawia się potrzeba analizy czynników średnioterminowych.

W Legacies argumentowałem, że zmiany polityczne zapoczątkowane w 1989 roku stawały się rewolucjami politycznymi tylko wtedy, gdy pociągały za sobą wymianę elit politycznych. Nie przekształcały się natomiast $\mathrm{w}$ rewolucje społeczne, ponieważ hierarchia społeczna i skład elit społecznych pozostawał niemal niezmieniony po 1989 roku. Elity późnego okresu totalitarnego zamieniły swój kapitał polityczny na ekonomiczny, wykorzystując nieskrywaną, czyli niechronioną przez prawo wolność do zawłaszczenia państwa i przekształciły swoją wolność w prawa własności w procesie prywatyzacji. Ówczesny system sądowniczy nie był w stanie ustanowić praworządności i nie zrobił tego. Przeciętni posttotalitarni obywatele nie byli w stanie przeciwstawić się ciągłości społecznej ani procesom przechwytywania państwa, ponieważ niewiele mogli na to nie poradzić. Ponadto przez większość dwudziestolecia pomiędzy zakończeniem się komunizmu a globalnym kryzysem kraje Europy Środkowej i Wschodniej cieszyły się dużym wzrostem gospodarczym, który - choć nierównomiernie - przekładał się na poprawę jakości życia. Wzrost gospodarczy i rosnące znaczenie gospodarcze dla międzynarodowych i zagranicznych firm oraz powstanie nowych instytucji, takich jak wolne media, stworzyło możliwości społecznego awansu nieznane przed upadkiem komunizmu. Kiedy jednak możliwości te gwałtownie zniknęły, „to, co zostało niegdyś przedwcześnie pochowane do grobu, teraz wraca jako zmora" (Lewicki 267). Obywatele węgier- 
scy i polscy zaczęli przyglądać się bliżej członkom i politycznym wpływom swoich elit. W ramach protestu zagłosowali na populistów, którzy jawili się jako wyraźnie oddzieleni od odsuwanych od władzy, pazernych elit, i udzielili im mandatu do zwalczania poprzedników. Wymiana skupionych na sobie postkomunistycznych polityków, sędziów i urzędników, niemających szacunku dla zasady praworządności, na równie egoistyczną grupę lojalnych jedynie wobec siebie nawzajem, nierespektujących prawa członków innej partii, przy jednoczesnym ograniczeniu niezależności instytucji stanowiących fundament liberalnej demokracji, nie była raczej zmianą na lepsze, ale populistyczni liderzy mogli przynajmniej obiecać wyborcom, że nie pozwolą na napływ imigrantów z Marsa tudzież innego równie prawdopodobnego miejsca przybyszów marzących o osiedleniu się w posttotalitarnej Europie Wschodniej zamiast potraktować ją jako „kraj tranzytowy” na drodze do Niemiec, Szwecji czy Wielkiej Brytanii.

Jak napisał Wierzchosławski:

zasadnicze pytanie wiąże się z kwestią, czy dysydentom udało się stworzyć takie ramy instytucjonalne, które stanowią zabezpieczenie przed pokusą populizmu, nie tylko tym, że oferują obywatelom stabilne i dobrze funkcjonujące struktury państwa szanującego ich indywidualną wolność, lecz także gwarantujące poczucie bezpieczeństwa (w tym i socjalnego) wszystkim grupom społecznym? Jeśli nie, to dlaczego do tego doszło? (Wierzchosławski 277).

Lub, jak to w kilku zgrabnych słowach ujął ten sam autor: „co powoduje, że skoro miało być tak dobrze, jest tak źle?!" (Wierzchosławski 276). W Legacies stawiam hipotezę, że przyczyną był brak alternatywnych elit posttotalitarnych. Totalitaryzm różni się od autorytaryzmu usiłowaniem stworzenia hierarchii społecznej z jedną klasą, co Krzysztof Brzechczyn wyjaśnia w ramach szerszej teorii społecznej Leszka Nowaka (1991). We wstępnej, rewolucyjnej fazie totalitaryzmu cel ten jest osiągany poprzez wyeliminowanie - wymordowanie, uwięzienie lub wygnanie - około $10 \%$ populacji. Po usunięciu przedtotalitarnych elit elity rewolucyjne zwracają się przeciwko własnym szeregom. Jak zauważa Brzechczyn, samolikwidacja elity totalitarnej wynikała z jej monopolu na władzę - stawała się jedyną możliwą drogą dalszego poszerzania zakresu władzy. Najpierw ginęli idealiści, zdezorientowani przez szczerość swoich przekonań. Tracąc stopniowo wiarę, mogli oni przetrwać jedynie na niższych szczeblach nowej drabiny społecznej (odpowiadam tu na trafne spostrzeżenie Brzechczyna o pozornej sprzeczności pomiędzy moim twierdzeniem, że idealiści zabijani są $\mathrm{w}$ fazie rewolucyjnej totalitaryzmu, a późniejszym twierdzeniem, że rozczarowują się w jego dalszych fazach).

W późnym okresie totalitarnym reżim usiłował zamrozić strukturę społeczną - zapobiegał pojawieniu się nowych, niezależnych elit, kontrolując poprzez partię mobilność społeczną, selekcjonując studentów według kryteriów politycznych 
i tłamsząc społeczeństwo obywatelskie, przestrzeń pomiędzy państwem a rodziną, w której elity mogą się wytworzyć niezależnie od władzy państwowej. Reżimy autorytarne $\mathrm{z}$ kolei eliminowały wyłącznie alternatywne elity polityczne i politycznych przeciwników, ignorując niepolityczne alternatywne elity oraz społeczeństwo obywatelskie. Na tym polega wyjątkowość totalitaryzmu. Jak podkreśliła Cristina Petrescu, jednym z głównych argumentów podnoszonych w Legacies jest niezbędność koncepcji totalitaryzmu do zrozumienia XX wieku i tego, co nastąpiło później. Jak zauważa autorka, kontrowersyjne jest zarówno znaczenie, jak i zastosowanie tej koncepcji. Znaczenie nadane jej przeze mnie prowadzi do podkreślania nieobecności alternatywnych elit społecznych i wytworzeniu się jednej hierarchii społecznej, co nigdy nie pokrywało się całkowicie z rzeczywistością, ponieważ władze państwowe nie były w stanie osiągnąć pełnej kontroli nad każdym zakątkiem kraju. Niemniej osiągnięta kontrola wystarczała do utrzymania hegemonii społecznej. Nie stosowano ekstremalnej przemocy i pojawiły się drobne społeczności dysydentów, nie dość jednak liczne, by zastąpić elity władzy po upadku reżimu. Garść byłych dysydentów w polityce i mediach (nie wszyscy zresztą byli liberalnymi demokratami) nie mogła zreformować instytucji i ustanowić praworządności w wymiarze sprawiedliwości i policji, o reformie gospodarki nie wspominając. Podstawowym, tragicznym dziedzictwem późnego totalitaryzmu była strategia rozwiązywania problemów społecznych poprzez znajdowanie znajomości celem obejścia absurdalnych i sztywnych, niereformowalnych instytucji i uregulowań. Ta praktyka społeczna, stosowana na szeroką skalę, oznaczała zmienianie społeczeństwa poprzez zmiany personalne zamiast podjęcia prób wprowadzenia reform prawnych i instytucjonalnych. Zamiast projektować dobrze działające instytucje, które mogłyby działać na podstawie odpowiednich zasad, reformatorzy zastępowali liderów politycznymi sojusznikami. W takich okolicznościach „zwalczanie korupcji” może przybrać formę przechwytywania państwa przez coraz to nowe kliki.

W moim wywodzie postulowałem, że koniec totalitaryzmu polegał na dostosowaniu niechronionych prawem wolności politycznych późnototalitarnych elit do ich interesów ekonomicznych. Michał Kwiecień pominął w mojej analizie odniesienia do rozróżnienia poziomów przechwycenia państwa, dokonanego przez Janine Wedel (Kwiecień). W Legacies odróżniam gospodarki, w których zawłaszczenie państwa wymagało stałej kontroli rządu z uwagi na fakt, że głównym źródłem przepływu gotówki były przychody ze sprzedaży zasobów naturalnych, niemożliwych do zlikwidowania czy też przeniesienia gdzieś indziej, od gospodarek pozbawionych zasobów naturalnych, w przypadku których bezpośrednim celem "grasujących bandytów", by użyć terminu Mancura Olsona, były najpłynniejsze aktywa, na przykład należące do monopoli bankowych i ubezpieczeniowych. Po przejęciu tego typu aktywów bieżące zainteresowanie rządowych elit gospodarczych ograniczało się do takiego manipulowania regulacjami, aby chronić monopole i móc wpływać na przebieg przetargów publicznych, co stanowiło częściowe przechwycenie 
państwa. Putinowska odbudowa nomenklatury przybrała z kolei formę, posługując się słowami Olsona, „bandytyzmu stacjonarnego” (Olson): aby czerpać korzyści ze sprzedaży energii, trzeba było przejąć państwo.

Populiści opanowali sztukę przejmowania państwa do perfekcji. Dziedzictwem demokracji liberalnej było z kolei zachowanie liberalnych instytucji, czego najdobitniejszym przykładem jest władza sądownicza w Stanach Zjednoczonych, dostatecznie niezależna i posiadająca wpływy, które pozwoliły im ograniczyć władzę egzekutywy metodami niedostępnymi dla państw posttotalitarnych. W Stanach Zjednoczonych zachowała się więc również wolność prasy, a takie instytucje jak Bank Centralny pozostały niezależne pomimo ciągłych prób ich osłabienia. W końcowym rozrachunku ścieżka zależności średniego zasięgu określana przez dziedzictwa totalitaryzmu okazuje się mieć znaczenie.

Ostateczne porównanie pomiędzy współczesnymi Stanami Zjednoczonymi a posttotalitarnymi państwami wydaje się jeszcze bardziej zaskakujące. Administracja Donalda Trumpa wykazuje wyraźne podobieństwo do byłych rządów dysydenckich, które przejmowały władzę po 1989 roku: ekstremalnie niską lojalność elit. Tak jak dysydenci nie mogli bez alternatywnych elit przeprowadzić społecznej rewolucji, tak jest również w przypadku Trumpa. Pośród członków elit zdolnych i chętnych do służenia jego administracji w zasadzie nie ma prawdziwych wyznawców populizmu ani nawet oportunistów, ponieważ nikt nie wierzy, że jego prezydentura będzie dość długa, by wynagrodzić współpracowników. Gdy brak jest takich alternatywnych elit, zarówno zasiedziałe elity, jak i istniejący system bronią się skutecznie i blokują zmiany te na lepsze i te na gorsze.

Przet. Agnieszka Wróblewicz

\section{BIBLIOGRAFIA}

Brzechczyn, Krzysztof. „Transformacja przywilejów władzy czy transformacja typów dominacji klasowej?” Porównania 24 (2019). S. 239-245.

Kwiecień, Michał. „Anatomia post-totalitaryzmu”. Porównania 24 (2019). S. 253-257.

Lewicki, Grzegorz. „Dziedzictwa i zombie. Dlaczego należy wspierać krótkoterminowe prognozy analizą zjawisk długoterminowych". Porównania 24 (2019). S. 265-270.

Nowak, Leszek. Power and Civil Society. Toward a Dynamic Theory of Real Socialism. New York: Greenwood Press, 1991.

Olson Mancur. “Dictatorship, Democracy and Development". American Political Science Review 87 (3) (1993). S. 567-576.

Petrescu, Cristina. „Zmiana symulowana. Totalitaryzm i to, co nastąpiło później”. Porównania 24 (2019). S. 259-263. 
AVIEZER TUCKER, DLACZEGO DZIEDZICTWA MAJA ZNACZENIE...

Petrescu, Dragoş. „Ograniczenia demokratycznej konsolidacji. Obalenie rozumu jako syndrom posttotalitarny". Porównania 24 (2019). S. 247-251.

Wierzchosławski, Piotr. „Dysydenci i nomadowie w państwach (nie tylko) posttotalitarnych. Czyli dlaczego tyle problemów, skoro jest tak dobrze?". Porównania 24 (2019). S. 271-280. 